\title{
Risk factors for explantation of iris-fixated phakic intraocular lenses
}

Citation for published version (APA):

Jonker, S. M. R., Van Averbeke, A. A. C., Berendschot, T. T. J. M., Saelens, I. E. Y., \& Nuijts, R. M. M. A. (2019). Risk factors for explantation of iris-fixated phakic intraocular lenses. Journal of Cataract and Refractive Surgery, 45(8), 1092-1098. https://doi.org/10.1016/j.jcrs.2019.03.009

Document status and date:

Published: 01/08/2019

DOI:

10.1016/j.jcrs.2019.03.009

Document Version:

Publisher's PDF, also known as Version of record

Document license:

Taverne

Please check the document version of this publication:

- A submitted manuscript is the version of the article upon submission and before peer-review. There can be important differences between the submitted version and the official published version of record.

People interested in the research are advised to contact the author for the final version of the publication, or visit the DOI to the publisher's website.

- The final author version and the galley proof are versions of the publication after peer review.

- The final published version features the final layout of the paper including the volume, issue and page numbers.

Link to publication

\footnotetext{
General rights rights.

- You may freely distribute the URL identifying the publication in the public portal. please follow below link for the End User Agreement:

www.umlib.nl/taverne-license

Take down policy

If you believe that this document breaches copyright please contact us at:

repository@maastrichtuniversity.nl

providing details and we will investigate your claim.
}

Copyright and moral rights for the publications made accessible in the public portal are retained by the authors and/or other copyright owners and it is a condition of accessing publications that users recognise and abide by the legal requirements associated with these

- Users may download and print one copy of any publication from the public portal for the purpose of private study or research.

- You may not further distribute the material or use it for any profit-making activity or commercial gain

If the publication is distributed under the terms of Article $25 \mathrm{fa}$ of the Dutch Copyright Act, indicated by the "Taverne" license above, 


\title{
Risk factors for explantation of iris-fixated phakic intraocular lenses
}

\author{
Soraya M.R. Jonker, MD, Annelies A.C. Van Averbeke, MD, Tos T.J.M. Berendschot, PhD, \\ Isabelle E.Y. Saelens, MD, PhD, Rudy M.M.A. Nuijts, $M D, P h D$
}

Purpose: To determine risk factors for explantation of iris-fixated phakic intraocular lenses (plOLs) with a maximum 17-year followup.

Setting: University Eye Clinic Maastricht, Maastricht UMC+, the Netherlands.

Design: Prospective case series.

Methods: Eyes that had implantation of 1 of various iris-fixated plOL models from 1998 to 2016 were evaluated. Primary outcome measures were the rate and proportion of $\mathrm{plOL}$ explantations and the survival time (ie, time to plOL explantation) in general and specifically as a result of cataract formation or endothelial cell loss (ECL).

Results: The study comprised 1037 eyes. The mean follow-up was 69.3 months \pm 52.8 (SD) and the mean preoperative age, $40.2 \pm 10.9$ years. The overall explantation rate was $12 \%$ after a mean of 166.1 months \pm 3.0 (standard error). Phakic IOL explantations were performed in $59 \%$ of eyes because of cataract formation and in $32 \%$ because of ECL. Shorter survival was seen with a higher preoperative age (hazard ratio [HR], 1.07/ $\mathrm{y} ; P<.001)$, longer axial length $(\mathrm{AL})(\mathrm{HR}, 1.10 / \mathrm{mm} ; P=.009)$, and smaller anterior chamber depth (ACD) (HR, 4.47/mm; $P<.001)$. Factors for shorter survival resulting from cataract were older preoperative age, longer $\mathrm{AL}$, and larger $\mathrm{ACD}$. Risk factors contributing to shorter survival resulting from ECL were a smaller $A C D$, lower endothelial cell density, and implantation with an Artisan hyperopia (toric) or Artiflex myopia (toric) IOL.

Conclusions: The explantation rate of iris-fixated plOLs was $12 \%$ after almost 14 years of follow-up, with $59 \%$ of plOL explantations caused by cataract formation and $32 \%$ caused by ECL. An older preoperative age, longer $\mathrm{AL}$, and smaller $\mathrm{ACD}$ were risk factors for a shorter survival.

J Cataract Refract Surg 2019; 45:1092-1098 @ 2019 ASCRS and ESCRS
$\mathrm{P}$ hakic intraocular lenses (pIOLs) have been used for many years in young (ie, prepresbyopic) patients unsuitable for laser refractive surgery. Three types of pIOLs have gained access to the market: anterior chamber angle-supported, anterior chamber iris-fixated, and posterior chamber. Multiple previous studies ${ }^{1-7}$ have found excellent refractive and visual results for all 3 pIOL types.

Although studies ${ }^{8-10}$ have assessed the short-term and long-term changes in visual and refractive outcomes as well as the endothelial cell density (ECD) after pIOL implantation, none has assessed the rate of explantation and risk factors for a shorter survival. Unlike anterior chamber angle-supported and posterior chamber pIOLs, the design of iris-fixated pIOLs has not been modified over time, allowing researchers to collect data over an extended period, thus increasing the suitability for long-term analyses. ${ }^{1,5,8}$

The aim of the current prospective follow-up study was to determine the reasons for explantation and risk factors for shorter survival in eyes with an Artisan myopia (toric), Artisan hyperopia (toric), or Artiflex myopia (toric) irisfixated pIOL (all Ophtec BV).

\section{PATIENTS AND METHODS}

This study evaluated eyes that had implantation of an iris-fixated pIOL from January 1998 to November 2016 at Maastricht, Maastricht University Medical Center, the Netherlands. Patients were prospectively evaluated preoperatively and 1 day, 1 week, and 1 , 3,6 , and 12 months during the first postoperative year. Regular follow-up continued with annual visits. The current study was performed in adherence with the tenets of the Declaration of Helsinki. The Maastricht University Medical Center Institutional Review

Submitted: December 20, 2018 | Final revision submitted: March 8, 2019 | Accepted: March 11, 2019

From the University Eye Clinic Maastricht (Jonker, Van Averbeke, Berendschot, Saelens, Nuijts), Maastricht University Medical Center, and the Department of Ophthalmology (Nuijts), Zuyderland Medical Center, Heerlen, the Netherlands.

Presented at the XXXVI Congress of the European Society of Cataract and Refractive Surgeons, Vienna, Austria, September 2018.

Corresponding author: Soraya M.R. Jonker, MD, University Eye Clinic Maastricht, Maastricht University Medical Center, PO Box 5800, 6202 AZ, Maastricht, the Netherlands. Email: soraya.jonker@mumc.nl. 
Board stated that medical ethical approval was not required for this study.

\section{Implantation Criteria}

Before pIOL implantation, patients had to be 18 years or older and have a stable refraction for at least 2 years. The anterior chamber depth (ACD) from the corneal endothelium to the anterior plane of the crystalline lens had to be at least $2.8 \mathrm{~mm}$ with a maximum clear lens rise of $600 \mu \mathrm{m} .{ }^{1,8,11,12}$ The criteria for the minimum preoperative ECD depended on age, with more than 2800 cells $/ \mathrm{mm}^{2}$ required for patients from 21 to 25 years old, more than 2650 cells/ $\mathrm{mm}^{2}$ for patients from 26 to 30 years old, more than 2400 cells/ $\mathrm{mm}^{2}$ for patients from 31 to 35 years old, more than 2200 cells/ $\mathrm{mm}^{2}$ for patients from 36 to 45 years old, and more than 2000 cells $/ \mathrm{mm}^{2}$ in patients older than 45 years. ${ }^{\mathrm{A}}$ This article does not contain data on patients treated with iris-fixated pIOLs who had keratoconus, irregular astigmatism, or corneal transplantation. Data on a subset of patients from the present study was previously presented. $3,8,9,13-18$

\section{Phakic Intraocular Lenses}

The Artisan myopia pIOL is a 1-piece poly(methyl methacrylate) (PMMA) rigid lens with a convex-concave optic and a total diameter of $8.5 \mathrm{~mm}$. The optic diameter is variable and depends on the required refractive correction; pIOLs with a power from -1.0 to -15.5 diopters (D) are available in a $6.0 \mathrm{~mm}$ optic diameter and powers from -1.0 to $-23.5 \mathrm{D}$ in a $5.0 \mathrm{~mm}$ optic diameter.

The Artisan hyperopia pIOL is a 1-piece PMMA rigid lens with a convex-concave optic and a spherical power ranging from +1.0 $\mathrm{D}$ to $+12.0 \mathrm{D}$. The total diameter is $8.5 \mathrm{~mm}$ and the optic diameter, $5.0 \mathrm{~mm}$.

The Artisan toric pIOL is a 1-piece PMMA rigid lens with a convex-concave optic, a spherical power ranging from +14.0 to $-22.0 \mathrm{D}$, and a cylindrical power up to $-7.5 \mathrm{D}$. The total diameter is $8.5 \mathrm{~mm}$ and the optic diameter, $5.0 \mathrm{~mm}$.

The Artiflex myopia pIOL is a 3-piece IOL with a polysiloxane optic and PMMA haptics. It is a foldable with a convex-concave optic and spherical power ranging from -2.0 to $-14.5 \mathrm{D}$. The total diameter is $8.5 \mathrm{~mm}$ and the optic diameter, $6.0 \mathrm{~mm}$.

The Artiflex toric pIOL is foldable lens with a convex-concave polysiloxane optic and PMMA haptics. The spherical power ranges from -1.0 to $-13.5 \mathrm{D}$ and the cylindrical power from -1.0 to $-5.0 \mathrm{D}$. The total diameter is $8.5 \mathrm{~mm}$ and the optic diameter, $6.0 \mathrm{~mm}$.

Intraocular lens power calculations were performed by the manufacturer using the van der Heijde formula. ${ }^{19}$

\section{Surgical Technique}

All surgeries were performed by the same surgeon (R.N.) at the University Eye Clinic Maastricht under general or local anesthesia. Previous studies $9,14,15, \mathrm{~A}$ described the surgical procedure and postoperative medication regimen.

\section{Patient Evaluation}

The preoperative examination consisted of subjective and cycloplegic refractions, Snellen uncorrected and corrected distance visual acuity measurements, slitlamp examination, Goldmann applanation tonometry, and fundoscopy. Additional measurements consisted of corneal topography (Orbscan, Bausch + Lomb, Inc.; Pentacam HR, Oculus Optikgeräte $\mathrm{GmbH}$; Sirius, Schwind eye-tech-solutions $\mathrm{GmbH} \&$ Co. KG), biometry (A2500, Sonomed Escalon; IOLMaster, Carl Zeiss Meditec AG), anterior segment optical coherence tomography (Visante, Carl Zeiss Meditec AG), and specular microscopy (Noncon Robo pachy SP9000 S/N PK1-1137; Topcon SP3000, Konan Medical, Inc.). All preoperative measurements were performed 1 week after removal of soft contact lenses and 2 weeks after removal of rigid gas-permeable contact lenses. Annual follow-up visits consisted of subjective refraction, Snellen uncorrected and corrected distance visual acuity measurements, slitlamp examination, tonometry, corneal topography, anterior segment optical coherence tomography, and specular microscopy.

Based on the known variation between specular microscopes and the influence of this variation on the correct calculation of endothelial cell loss (ECL), the same specular microscope used during preoperative measurements was used for all follow-up measurements in each eye. ${ }^{20,21}$ Per protocol, analysis of the mean ECD in each eye was calculated by determining the mean of 3 consecutive measurements of 50 central endothelial cells using the manual center-to-center method. ${ }^{22}$

\section{Outcome Measures}

The primary outcome measures were the rate explantation of the each pIOL model and the proportion of eyes that had pIOL explantation because of cataract formation or ECL. Survival analyses were performed to assess how long it took until the pIOL was explanted in $50 \%$ of eyes (ie, median survival). The secondary outcome measures were the mean survival and time until $25 \%$ of pIOLs were explanted (ie, 75\% survival). Survival analyses were performed with the following 3 endpoints: explantation in general, explantation because of cataract formation, and explantation because of ECL.

The preoperative patient age, axial length (AL), ACD, and endothelial cell density (ECD) were evaluated as possible contributors to survival, as were the intraocular pressure (IOP), patient sex, pIOL type, and refractive error (myopia versus hyperopia). To assess the effect of the different pIOL models, the following 3 subgroups were created: rigid myopia (toric), consisting of rigid myopia pIOLs (ie, Artisan myopia and Artisan myopia toric), rigid hyperopia (toric), consisting of rigid hyperopia pIOLs (ie, Artisan hyperopia and Artisan hyperopia toric); and foldable myopia (toric), consisting of foldable myopia pIOLs.

\section{Statistical Analysis}

Statistical analysis was performed using SPSS for Windows software (version 23, IBM Corp.). Descriptive analyses were performed to compute mean $\pm \mathrm{SD}$ of the preoperative characteristics, and analysis of variance was used to test for preoperative between-group differences. Kaplan-Meier analyses were performed to assess the number of explantations as well as to assess the mean, $75 \%$, and median survival. Additional univariate and multivariate Cox regression analyses were performed to identify risk factors for a shorter survival. A $P$ value less than 0.05 was considered statistically significant in all analyses.

Eight probable risk factors (ie, preoperative age, sex, ACD, AL, ECD, IOP, manifest refractive spherical equivalent [MRSE], lens group) were evaluated in univariate Cox regression analyses. Risk factors identified as significant in univariate analyses were combined in a multivariate Cox regression analysis followed by backward exclusion of insignificant risk factors until only significant risk factors remained. This process was repeated 3 times to report risk factors for pIOL explantation in general, pIOL explantation resulting from cataract formation, and pIOL explantation resulting from ECL. The output of the risk-factor analyses is described as a hazard ratio (HR), indicating the relative risk for the event to take place. An HR less than 1 indicates a lower risk for a shorter survival, whereas an HR greater than 1 indicates a higher risk for a shorter survival.

Numerical variables were implemented as continuous risk factors in all models, resulting in an HR per cells $/ \mathrm{mm}^{2}$ or per year change. The pIOL type was implemented as a categorical variable for comparison between groups. 
Table 1. Preoperative characteristics in patients with iris-fixated phakic intraocular lenses.

\begin{tabular}{|c|c|c|c|c|c|}
\hline Parameter & $\begin{array}{l}\text { Total } \\
\text { Cohort }\end{array}$ & $\begin{array}{c}\text { Artisan Myopia } \\
\text { (Toric) }\end{array}$ & $\begin{array}{c}\text { Artisan Hyperopia } \\
\text { (Toric) }\end{array}$ & $\begin{array}{l}\text { Artiflex Myopia } \\
\text { (Toric) }\end{array}$ & $P$ Value \\
\hline Implants/patients (n) & $1037 / 522$ & $466 / 255$ & $77 / 45$ & $494 / 270$ & - \\
\hline Mean age $(y)$ & $40.2 \pm 10.9$ & $41.1 \pm 10.8$ & $37.3 \pm 11.7$ & $39.7 \pm 10.9$ & $.007^{*}$ \\
\hline Males/females (\%) & $38 / 62$ & $38 / 62$ & $53 / 47$ & $36 / 64$ & - \\
\hline Mean AL (mm) & $27.04 \pm 2.27$ & $28.08 \pm 2.28$ & $21.87 \pm 1.53$ & $26.84 \pm 1.31$ & $<.001^{*}$ \\
\hline Mean ACD (mm) & $3.63 \pm 0.35$ & $3.67 \pm 0.35$ & $3.39 \pm 0.35$ & $3.63 \pm 0.33$ & $<.001^{*}$ \\
\hline Mean IOP $(\mathrm{mm} \mathrm{Hg})$ & $15.1 \pm 3.1$ & $14.7 \pm 3.0$ & $14.8 \pm 3.1$ & $15.4 \pm 2.9$ & $.008^{*}$ \\
\hline Mean ECD $\left(\right.$ cells $\left./ \mathrm{mm}^{2}\right)$ & $2713 \pm 350$ & $2669 \pm 367$ & $2739 \pm 401$ & $2748 \pm 322$ & $.002^{*}$ \\
\hline Mean MRSE (D) & $-9.63 \pm 5.87$ & $-12.50 \pm 5.04$ & $3.80 \pm 2.03$ & $-9.13 \pm 2.84$ & $<.001^{*}$ \\
\hline
\end{tabular}

Means $\pm S D$

$\mathrm{ACD}=$ anterior chamber depth; $\mathrm{AL}=$ axial length; $\mathrm{ECD}=$ endothelial cell density; IOP $=$ intraocular pressure; MRSE $=$ manifest refraction spherical equivalent

*Statistically significant difference

\section{RESULTS}

The study evaluated 1037 eyes. An Artisan myopia pIOL was implanted in 381 eyes, an Artisan hyperopia pIOL in 38 eyes, an Artisan toric pIOL in 130 eyes, an Artiflex myopia pIOL in 299 eyes, and an Artiflex toric pIOL in 199 eyes. Table 1 shows the preoperative characteristics, including age, sex, AL, ACD, IOP, ECD, and MRSE, in the entire cohort and in each pIOL subgroup.

Overall, explantation was performed in $12 \%$ of eyes (120/ 1037). The main reasons for explantation were cataract formation and ECL (Table 2). Explantation was performed for other reasons in 11 eyes (9\%) as follows: high IOP (5 eyes), pIOL decentration after a blunt trauma (1 eye), after transpars plana vitrectomy and phacoemulsification for retinal detachment repair (1 eye), visual loss unrelated to cataract formation (1 eye), pIOL decentration and visual impairment ( 1 eye), diplopia caused by anisometropia ( 1 eye), and pigment depositions on the optic ( 1 eye). Figure 1 shows the proportion of eyes requiring pIOL explantation because of cataract formation or ECL in the total cohort and in each pIOL subgroup. Table 2 shows the number of pIOL explantations and the mean (i.e. 50\%), 75\%, and median survival in the total cohort and in each subgroup.

\section{Risk Factors for Explantation}

The mean patient age at IOL explantation was $54.6 \pm 8.3$ years, with a mean of 166.1 months until explantation (Table 2). Univariate risk factors for a shorter

\begin{tabular}{|c|c|c|c|c|}
\hline Parameter & Total Cohort & Artisan Myopia (Toric) & $\begin{array}{c}\text { Artisan Hyperopia } \\
\text { (Toric) }\end{array}$ & Artiflex Myopia (Toric) \\
\hline Implants/patients (n) & $1037 / 522$ & $466 / 255$ & $77 / 45$ & $494 / 270$ \\
\hline Mean follow-up, mo & $69.3 \pm 52.8$ & $90.0 \pm 59.7$ & $68.3 \pm 44.9$ & $50.3 \pm 37.7$ \\
\hline \multicolumn{5}{|l|}{ plOL explantation } \\
\hline Total explantations, n (\%) & $120(12)$ & $80(17)$ & $9(12)$ & $31(6)$ \\
\hline Explantations at 5 y, n (\%) & $28(3)$ & $13(3)$ & $1(1)$ & $14(3)$ \\
\hline Explantations at $10 \mathrm{y}, \mathrm{n}(\%)$ & $78(8)$ & $43(9)$ & $8(10)$ & $27(5)$ \\
\hline Mean survival (mo) \pm SEM & $166.1 \pm 3.0$ & $168.3 \pm 3.3$ & $149.0 \pm 8.9$ & $128.5 \pm 2.6$ \\
\hline $75 \%$ survival $(\mathrm{mo}) \pm \mathrm{SEM}$ & $134.3 \pm 3.9$ & $138.0 \pm 6.6$ & $119.2 \pm 10.5$ & $126.6 \pm 12.8$ \\
\hline Median survival (mo) & 182.9 & 182.9 & * & * \\
\hline \multicolumn{5}{|c|}{ Cataract as reason for plOL explantation } \\
\hline Total explantations, n (\%) & $71(7)$ & $50(11)$ & $2(3)$ & $19(4)$ \\
\hline Explantations at $5 \mathrm{y}, \mathrm{n}(\%)$ & $16(2)$ & $7(2)$ & NA & $9(2)$ \\
\hline Explantations at $10 \mathrm{y}, \mathrm{n}(\%)$ & $49(5)$ & $30(6)$ & $2(3)$ & $17(3)$ \\
\hline Mean survival $(m o) \pm$ SEM & $181.4 \pm 2.5$ & $181.5 \pm 2.9$ & $173.7 \pm 4.3$ & $134.5 \pm 2.3$ \\
\hline $75 \%$ survival $(\mathrm{mo}) \pm$ SEM & * & * & * & * \\
\hline Median survival (mo) & * & * & * & * \\
\hline \multicolumn{5}{|c|}{$\mathrm{ECL}$ as reason for pIOL explantation } \\
\hline Total explantations, n (\%) & $38(4)$ & $22(5)$ & $6(8)$ & $10(2)$ \\
\hline Explantations at 5 y, n (\%) & $5(<1)$ & $2(<1)$ & $3(<1)$ & NA \\
\hline Explantations at $10 \mathrm{y}, \mathrm{n}(\%)$ & $18(2)$ & $5(1)$ & $8(2)$ & $5(6)$ \\
\hline Mean survival $(\mathrm{mo}) \pm \mathrm{SEM}$ & $187.0 \pm 2.7$ & $190.5 \pm 2.7$ & $155.9 \pm 8.6$ & $137.1 \pm 2.3$ \\
\hline $75 \%$ survival $(\mathrm{mo}) \pm \mathrm{SEM}$ & $180.1 \pm 3.8$ & $180.1 \pm 4.1$ & $121.7 \pm 3.1$ & * \\
\hline Median survival (mo) & * & * & * & * \\
\hline
\end{tabular}




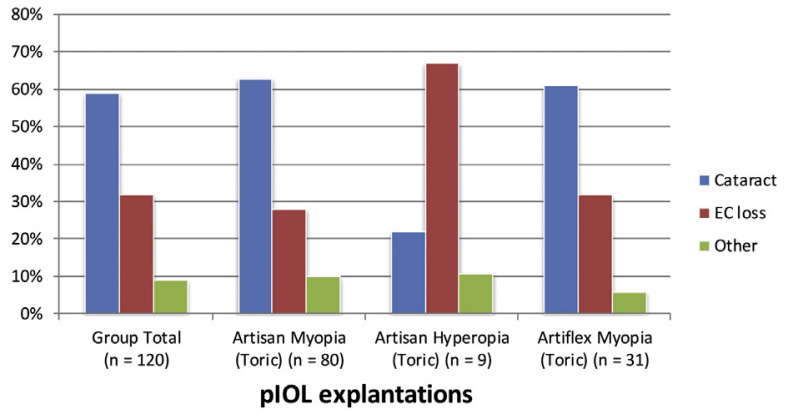

Figure 1. Reasons for pIOL explantation pIOLs ( $E C=$ endothelial cell; $\mathrm{n}=$ number of eyes; $\mathrm{plOL}=$ phakic intraocular lens).

survival in general were a higher preoperative age $(P<.001)$, longer AL $(P=.023)$, smaller preoperative ACD $(P<.001)$, and lower preoperative ECD $(P<.001)$. After insignificant $(P>.05)$ risk factors were removed using multivariate Cox regression analysis, the final model identified a higher preoperative age (HR, $1.07 / \mathrm{y} ; 95 \%$ confidence interval [CI]; 1.04-1.09; $P<.001)$, longer AL (HR, 1.10/mm; 95\% CI, 1.02-1.18; $P=.009)$, and smaller ACD (HR, $4.47 / \mathrm{mm} ; 95 \% \mathrm{CI}$, 2.43-8.22; $P<.001$ ) as risk factors for a shorter survival. Figure 2 shows the survival curve for pIOL explantation in general.

\section{Risk Factors for Explantation Resulting from Cataract Formation}

The mean survival until pIOL explantation resulting from cataract formation was 181.4 months (Table 2); explantation was performed at a mean age of $56.2 \pm 8.0$ years. A higher preoperative age $(P<.001)$, longer $\mathrm{AL}$ $(P<.001)$, larger preoperative $\operatorname{ACD}(P=.004)$, and lower $\operatorname{ECD}(P=.008)$ were identified as significant risk factors for a shorter survival in univariate Cox regression analyses. The final multivariate Cox regression analysis pointed toward a higher preoperative age (HR, 1.09/y; 95\% CI, 1.06-1.13; $P<.001$ ), longer AL (HR, 1.79/mm; 95\% CI, $1.49-2.15 ; P<.001$ ), and larger ACD (HR, 5.29/mm; 95\% CI, 2.265-12.38; $P<.001)$ as risk factors for a shorter

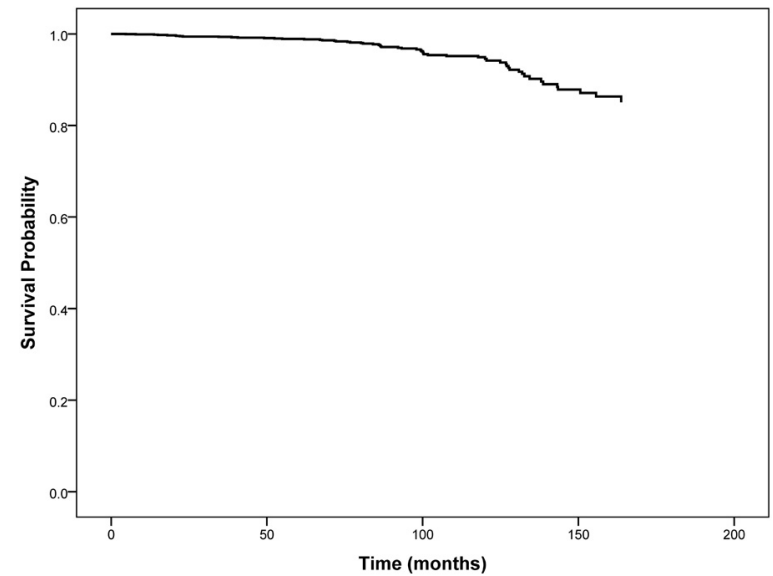

Figure 3. Survival for reaching phakic intraocular lens explantation related to cataract formation in total cohort.

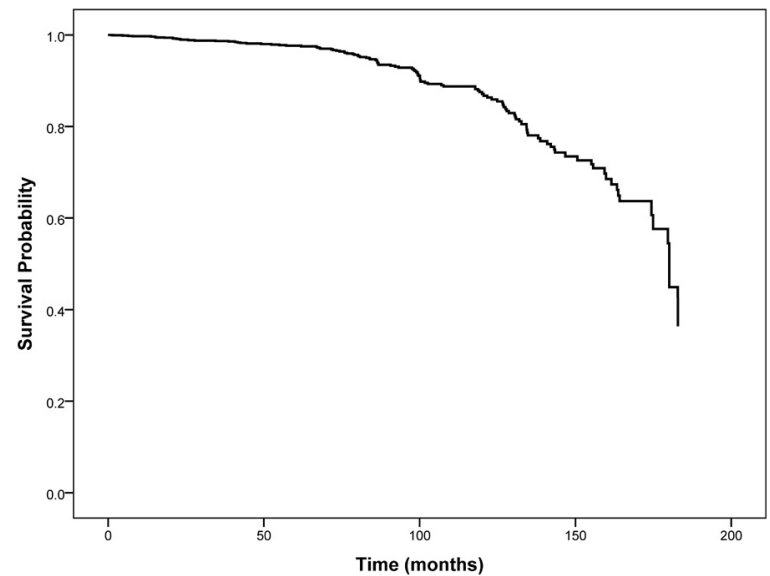

Figure 2. Survival curve for reaching phakic intraocular lens explantation in total cohort.

survival. Figure 3 shows the survival curve for pIOL explantation because of cataract formation.

\section{Risk Factors for Explantation Resulting from Endothelial Cell Loss}

Explantation related to ECL was performed at a mean age of $53.7 \pm 7.8$ years, with a mean survival of 187.0 months (Table 2). The mean ACD and ECD at the time of explantation were $3.20 \pm 0.28 \mathrm{~mm}$ and $1254 \pm 371 \mathrm{cells} / \mathrm{mm}^{2}$, respectively.

Univariate Cox regression analyses identified a higher preoperative age $(P=.008)$, female sex $(P=.003)$, shorter $\operatorname{AL}(P=.004)$, smaller preoperative $\operatorname{ACD}(P<.001)$, lower $\operatorname{ECD}(P<.001)$, and hyperopic refractive error $(P=.008)$ as risk factors for a shorter survival. Subsequently, the influence of the pIOL group was evaluated, showing an increased risk for a shorter survival after implantation of a rigid hyperopic (toric) or foldable myopic (toric) pIOL compared with implantation of a rigid myopic (toric) pIOL $(P=.002)$. The final multivariate analyses identified a smaller preoperative ACD (HR, 9.62/mm; 95\% CI, 2.97 31.17; $P<.001)$ and lower ECD (HR, $1.002 / \mathrm{cells} / \mathrm{mm}^{2}$; 95\% CI, 1.001-1.002; $P<.001)$ as factors increasing

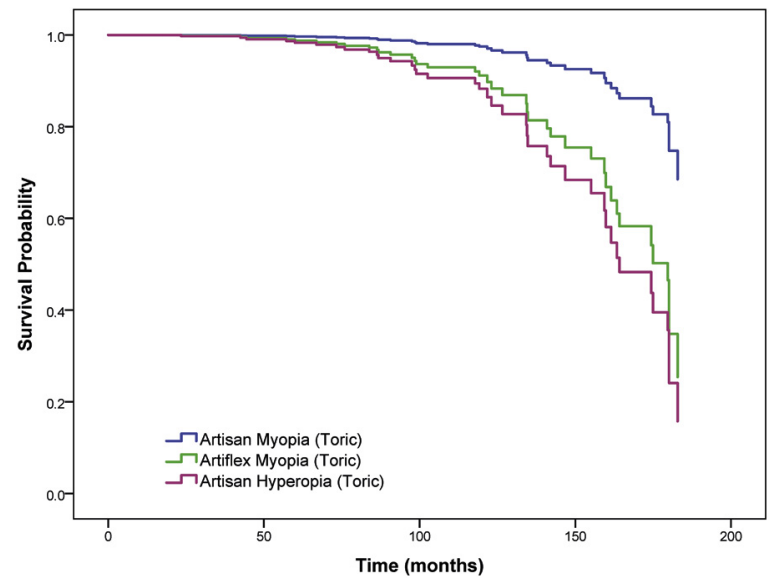

Figure 4. Survival curve for reaching phakic intraocular lens explantation related to endothelial cell loss. 
Table 3. Previous studies reporting explantation rates in eyes with iris-fixated plOL.

\begin{tabular}{|c|c|c|c|c|c|c|c|c|}
\hline \multirow[b]{2}{*}{ Author*/Year } & \multirow[b]{2}{*}{ plOL Type } & \multirow[b]{2}{*}{ Eyes (n) } & \multirow[b]{2}{*}{ Pts (n) } & \multirow[b]{2}{*}{ Follow-up (Y) } & \multicolumn{4}{|c|}{ Explantation (\%) } \\
\hline & & & & & Total & Cataract & ECL & Remarks \\
\hline Budo/2000 23 & Artisan myopia & 249 & NR & 3 & 2.80 & 1.20 & 0.40 & $\begin{array}{l}\text { Other reasons for } \\
\text { explantation } \\
\text { not reported }\end{array}$ \\
\hline Tahzib/2007 ${ }^{4}$ & Artisan myopia & 89 & 49 & 10 & 2.25 & 2.25 & NA & - \\
\hline Güell/2008 24 & Artisan myopia & 101 & 61 & 5 & 1.25 & 0.50 & 0.75 & $\begin{array}{l}\text { Two explanted after } \\
3 \text { years due to cataract; } \\
2 \text { explanted due to ECL } \\
\text { after } 3 \text { y, } 1 \text { after } 5 \text { y }\end{array}$ \\
\hline Saxena/2008 & $\begin{array}{l}\text { Artisan myopia (toric), } \\
\text { Artiflex myopia }\end{array}$ & 318 & NR & $2.9^{+}$ & 1.26 & 1.26 & NA & - \\
\hline Silva/2008 & Artisan myopia & 19 & NR & 5 & 7.60 & 3.80 & NA & $\begin{array}{l}\text { One explantation due to } \\
\text { bothersome glare and } \\
\text { halos }\end{array}$ \\
\hline Stulting/2008 26 & Artisan myopia & 1179 & 662 & 3 & 1.10 & 0.25 & NR & $\begin{array}{l}\text { Other reasons for } \\
\text { explantation not } \\
\text { reported }\end{array}$ \\
\hline Titiyal/2012 27 & Artisan myopia & 85 & 44 & 5 & 1.17 & NA & 1.17 & $\begin{array}{l}\text { Explantation caused by } \\
\text { early corneal } \\
\text { decompensation after } \\
\text { dislocation due to } \\
\text { insufficient enclavation }\end{array}$ \\
\hline Moshirfar/2014 ${ }^{28}$ & Artisan myopia & 213 & NR & $5.6+$ & 2.76 & 2.30 & 0.92 & $\begin{array}{l}\text { Median time to } \\
\text { explantation } 9.3 \text { years; } \\
\text { both cataract and ECL } \\
\text { in } 1 \text { eye }\end{array}$ \\
\hline Kamiya/2017 29 & NR (iris-fixated) & 50 & NR & 0.33 & 0.20 & NA & NA & $\begin{array}{c}\text { One explantation because } \\
\text { of bothersome halos }\end{array}$ \\
\hline
\end{tabular}

$\mathrm{ECL}=$ endothelial cell loss; $\mathrm{NA}=$ not applicable; $\mathrm{NR}=$ not reported; plOL = phakic intraocular lens; Pts = patients

*First author

${ }^{\dagger}$ Mean

the risk for a shorter survival and identified implantation of a rigid hyperopic (toric) (HR, 3.09; 95\% CI, 1.09-8.77, $P=.034$ ) or foldable myopic (toric) pIOL ( $\mathrm{HR}=4.45$, 95\% CI, 1.70-11.69, $P=.002$ ) as a risk factor compared with implantation of a rigid myopic (toric) pIOL. There was no significant difference in risk for ECL-related pIOL explantation between eyes with a rigid hyperopic (toric) or foldable myopic (toric) pIOL $(P=.58)$. Figure 4 shows the 3 survival curves corresponding to ECL-related explantation in all subgroups.

\section{DISCUSSION}

To our knowledge, this prospective study is the first to use survival analyses to evaluate the explantation rate, time to explantation (ie, survival), and risk factors for explantation of iris-fixated pIOLs in a single-center single-surgeon setting.

The mean follow-up in this study ranged from 90 months in the rigid myopic (toric) (Artisan) group to 50 months in the foldable myopic (toric) (Artiflex) group, which is longer than in most previous studies of iris-fixated pIOLs; the follow-up was 50 months or less in the vast majority of these studies. ${ }^{4,10,23-35}$ Only 9 of these studies reported pIOL explantations as well as the reason for pIOL explantation (Table 3). ${ }^{4,10,23-29}$ In this study, the explantation rate was $12 \%$ (17\% rigid myopic [toric] pIOLs after a mean of 168 months; $12 \%$ rigid hyperopic [toric] pIOLs after a mean of 110 months; $6 \%$ foldable myopic [toric] pIOLs after a mean of 127 months).

Explantation rates have been reported only in studies of rigid pIOLs. The explantation rate in these studies was highly variable $\left(0.2 \%\right.$ after 4 months $^{29} ; 1.1$ to $2.8 \%$ after 3 years $^{10,23,26} ; 1.2 \%$ to $7.6 \%$ after 5 to 6 years $^{4,24,25,27,28}$; $2.3 \%$ after 10 years $\left.^{4}\right)$. In the current study, all 3 groups had explantation rates similar to the rates in these previous papers after 5 years ${ }^{4,24,25,27,28}$; however, explantation rates after 10 years were slightly higher in our groups than in a previous study. ${ }^{4}$

The median survival in all groups combined was 183 months, similar to the median survival in the rigid myopic (toric) group. The median survival could not be computed in the rigid hyperopic (toric) and foldable myopic (toric) groups because of too few explantations. There were no significant differences in the mean followup between pIOL groups, even though the successive launch dates of the different pIOL types resulted in fewer rigid hyperopic (toric) pIOLs and foldable myopic (toric) pIOLs reaching a 10-year follow-up. 
To aid clinicians in their preoperative counseling, we performed supplementary analyses computing how long it would take until pIOL explantation is performed in $25 \%$ of patients. Referred to as $75 \%$ survival in this paper, it took 119 to 138 months until $25 \%$ of pIOLs would be explanted depending on the subgroup. In the rigid hyperopic (toric) group, the $25 \%$ pIOL explantation threshold resulting from ECL was reached after a significantly shorter follow-up than in the rigid myopic (toric) group (122 months versus 180 months). Unfortunately, because of the small number of explantations, it was not possible to compute this value for cataract formation as an indication for explantation. No previous study performed any of these analyses for angle-supported or iris-fixated pIOLs, and only 1 study ${ }^{36}$ reported survival for posterior chamber pIOLs. In the latter study, cataract-related explantation rates after implantation of an ICL V4 posterior chamber pIOL (STAAR Surgical Co.) were $4.9 \%$ at 5 years and $18.3 \%$ at 10 years. Neither the $75 \%$ survival nor the median survival was computed in this paper; however, the reported survival curve shows a trend similar to that in our study, with slightly higher rates of explantation 10 years after pIOL implantation. ${ }^{36}$ As reflected in the median survival, a large number of explantations in our study took place after more than 10 years, which we attribute to the steepened decline in survival in the final years of follow-up (Figure 4).

The main reason for explantation in the current study was cataract formation in the myopic (toric) groups and ECL in the hyperopic (toric) group. The results in the myopic groups are in line with earlier findings in the literature describing cataract formation as an age-related process occurring at a younger age in a highly myopic (ie, longer AL, larger ACD) target group. ${ }^{37,38}$ Cataract formation was not related to the iris fixation of the pIOL per se, given that early postoperative cataract formation was not detected. The etiology of ECL in eyes with a pIOL is not completely understood; however, consensus has been reached regarding the importance of an adequate preoperative ECD and sufficient distance between the PIOL and the corneal endothelium as potentially protecting against increased ECL. ${ }^{9,10,16}$ A shallow anterior chamber, as in hyperopic eyes, will bring the iris-fixated pIOL closer to the endothelium. Hypotheses suggest that intermittent contact between the edges of the PIOL and the endothelium result in exaggerated ECL. ${ }^{8,39,40}$ However, dynamic studies showing minimal movement of the iris-fixated pIOL during accommodation and taking into account that patients are strictly forbidden to rub their eyes postoperatively seem to contradict this theory. ${ }^{41}$ Also, application of strict preoperative safety margins for the distance between the pIOL and the central and peripheral corneal endothelium, as performed in this study, is believed to protect the patient against increased ECL. Other etiologies of ECL might be subclinical inflammation and changes in aqueous humor flow that disturb the supply of nutrients or the disposal of waste material, creating a cytotoxic environment in which endothelial cell death increases. ${ }^{42,43}$ Most likely, a combination of the above is responsible for the differences in ECL, as shown in the current study and a previous paper. ${ }^{13}$

In summary, the current study assessed the survival of 3 subgroups of iris-fixated pIOLs. Because pIOLs are implanted in relatively young, healthy, phakic eyes, it is important to analyze the long-term safety of these IOLs. Our results can aid surgeons during preoperative counseling and inform patients about the survival profile of irisfixated pIOLs. Because we detected a steep decline in survival in the final years of follow-up, we recommend that patients having implantation of iris-fixated pIOLs be informed preoperatively and actively approached postoperatively to comply with a strict long-term follow-up regimen including ECD measurements on a regular (bi) annual basis to detect and monitor ECL at an early stage.

\section{WHAT WAS KNOWN}

- The presence of a phakic intraocular lens (pIOL) increases annual endothelial cell loss (ECL).

- A known risk factor for increased ECL after plOL implantation is a smaller anterior chamber depth.

- Cataract formation occurs at an earlier age in highly myopic patients.

\section{WHAT THIS PAPER ADDS}

- Explantation rates of iris-fixated plOLs increased after 10 years of follow-up.

- Long-term follow-up of iris-fixated plOLs is mandatory because cataract formation and ECL were reasons for explantation in one third and two thirds of cases, respectively.

\section{REFERENCES}

1. Güell JL, Morral M, Kook D, Kohnen T. Phakic intraocular lenses. Part 1: his torical overview, current models, selection criteria, and surgical techniques. J Cataract Refract Surg 2010; 36:1976-1993

2. Barsam A, Allan BDS. Excimer laser refractive surgery versus phakic intraocular lenses for the correction of moderate to high myopia. Cochrane Database Syst Rev (5) Art. No. CD 007679

3. Doors M, Budo CJ, Christiaans BJ, Luger M, Marinho AAP, Dick HB, Güell JL, Nuijts RMMA. Artiflex toric foldable phakic intraocular lens: short-term results of a prospective European multicenter study. Am J Ophthalmol 2012; 154:730-739

4. Tahzib NG, Nuijts RM, Wu WY, Budo CJ. Long-term study of Artisan phakic intraocular lens implantation for the correction of moderate to high myopia; ten-year follow-up results. Ophthalmology 2007; 114:1133-1142

5. Kohnen T, Kook D, Morral M, Güell JL. Phakic intraocular lenses. Part 2: results and complications. J Cataract Refract Surg 2010; 36:2168-2194

6. Kohnen T, Maxwell WA, Holland S. Correction of moderate to high myopia with a foldable, angle-supported phakic intraocular lens; results from a 5-year open-label trial. Ophthalmology 2016; 123:1027-1035

7. Shimizu K, Kamiya K, Igarashi A, Kobashi H. Long-term comparison of posterior chamber phakic intraocular lens with and without a central hole (hole ICL and conventional ICL) implantation for moderate to high myopia and myopic astigmatism [consort-compliant article]. Medicine 2016; 95:e3270

8. Jonker SMR, Berendschot TTJM, Ronden AE, Saelens IEY, Bauer NJC, Nuijts RMMA. Long-term endothelial cell loss in patients with Artisan myopia and Artisan toric phakic intraocular lenses; 5- and 10-year results. Ophthalmology 2018; 125:486-494 
9. Doors M, Berendschot TTJM, Webers CAB, Nuijts RMMA. Model to predict endothelial cell loss after iris-fixated phakic intraocular lens implantation. Invest Ophthalmol Vis Sci 2010; 51:811-815

10. Saxena R, Boekhoorn SS, Mulder PGH, Noordzij B, van Rij G, Luyten GPM Long-term follow-up of endothelial cell change after Artisan phakic intraocular lens implantation. Ophthalmology 2008; 115:608-613.e1

11. Baikoff G. Anterior segment OCT and phakic intraocular lenses: a perspective. Journal of cataract and refractive surgery 2006; 32:1827-1835

12. Baikoff G, Bourgeon G, Jodai HJ, Fontaine A, Viera Lellis F, Trinquet $L$. Pigment dispersion after Artisan phakic intraocular lenses; crystalline lens rise as a safety criterion. J Cataract Refract Surg 2005; 31:674-680

13. Jonker SMR, Berendschot TTJM, Ronden AE, Saelens IEY, Bauer NJC, Nuijts RMMA. Five-year endothelial cell loss after implantation with Artiflex Myopia and Artiflex Toric phakic intraocular lenses. Am J Ophthalmol 2018; 194:110-119

14. Doors M, Eggink FA, Webers CAB, Nuijts RMMA. Late-onset decentration of iris-fixated phakic intraocular lenses: a case series. Am J Ophthalmo 2009: 147:997-1003

15. Doors M, Berendschot TJM, Hendrikse F, Webers CAB, Nuijts RMMA Value of preoperative phakic intraocular lens simulation using optical coherence tomography. J Cataract Refract Surg 2009; 35:438-443

16. Doors M, Cals DWJK, Berendschot TJJM, de Brabander J, Hendrikse F, Webers CAB, Nuijts RMMA. Influence of anterior chamber morphometrics on endothelial cell changes after phakic intraocular lens implantation. J Cataract Refract Surg 2008; 34:2110-2118

17. Visser N, Berendschot TTJM, Bauer NJC, Nuijts RMMA. Vector analysis of corneal and refractive astigmatism changes following toric pseudophakic and toric phakic IOL implantation. Invest Ophthalmol Vis Sci 2012 53:1865-1873

18. Aerts AAS, Jonker SMR, Wielders LHP, Berendschot TTJM, Doors M, De Brabander J, Nuiits RMMA. Phakic intraocular lens: two-year results and comparison of endothelial cell loss with iris-fixated intraocular lenses. J Cataract Refract Surg 2015; 41:2258-2265

19. van der Heijde GL, Fechner PU, Worst JGF. Optische Konsequenzen der Implantation einer negativen Intraokularlinse bei myopen Patienten [[Optical consequences of implantation of a concave intraocular lens patients with myopia]]. Klin Monbl Augenheilkd 1988; 193:99-102

20. Cheung SW, Cho P. Endothelial cells analysis with the TOPCON specular microscope SP-2000P and IMAGEnet system. Curr Eye Res 2000; 21:788-798

21. Prinz A, Varga J, Findl $O$. Reliability of a video-based noncontact specular microscope for assessing the corneal endothelium. Cornea 2007 26:924-929

22. McCarey BE, Edelhauser HF, Lynn MJ. Review of corneal endothelial specular microscopy for FDA clinical trials of refractive procedures, surgical de vices, and new intraocular drugs and solutions. Cornea 2008; 27:1-16

23. Budo C, Hessloehl JC, Izak M, Luyten GPM, Menezo JL, Sener BA, Tassignon MJ, Termote H. Worst JGF. Multicenter study of the Artisan phakic intraocular lens. J Cataract Refract Surg 2000; 26:1163-1171

24. Güell JL, Morral M, Gris O, Gaytan J, Sisquella M, Manero F. Five-year follow-up of 399 phakic Artisan-Verisyse implantation for myopia, hyperopia, and/or astigmatism. Ophthalmology 2008; 115:1002-1012

25. Silva RA, Jain A, Manche EE. Prospective long-term evaluation of the efficacy, safety, and stability of the phakic intraocular lens for high myopia. Arch Ophthalmol 2008; 126:775-781

26. Stulting RD, John ME, Maloney RK, Assil KK, Arrowsmith PN Thompson VM, for the U.S. Verisyse Study Group. Three-year results of Artisan/Nerisyse phakic intraocular lens implantation; results of the United States Food and Drug Administration Clinical Trial. Ophthalmology 2008; 115:464-472.e1

27. Titiyal JS, Sharma N, Mannan R, Pruthi A, Vajpayee RB. Iris-fixated intraocular lens implantation to correct moderate to high myopia in Asian-Indian eyes: five-year results. Journal of cataract and refractive surgery 2012 ; 38:1446-1452

28. Moshirfar M, Imbornoni LM, Ostler EM, Muthappan V. Incidence rate and occurrence of visually significant cataract formation and corneal decom pensation after implantation of Verisyse/Artisan phakic intraocular lens. Clin Ophthalmol 2014: 8:711-716

29. Kamiya K, Igarashi A, Hayashi K, Negishi K, Sato M, Bissen-Miyajima H, on behalf of the Survey Working Group of the Japanese Society of Cataract and Refractive Surgery. A multicenter prospective cohort study on refractive surgery in 15011 eyes. Am J Ophthalmol 2017: 175:159-168

30. Yuan X, Ping HZ, Hong WC, Yin D, Ting Z. Five-year follow-up after anterior iris-fixated intraocular lens implantation in phakic eyes to correct high myopia. Eye 2012; 26:321-326
31. Ruckhofer J, Seyeddain O, Dexl AK, Grabner G, Stoiber J. Correction of myopic astigmatism with a foldable iris-claw toric phakic intraocular lens: short-term follow-up. J Cataract Refract Surg 2012; 38:582-588

32. Ozertürk Y, Kubaloglu A, Sari ES, Koytak A, Capkin M, Akçay L, Evcili PS Foldable iris-fixated phakic intraocular lens implantation for the correction of myopia: two years of follow-up. Indian J Ophthalmol 2012; 60:23-28

33. Muñoz G, Cardoner A, Albarrán-Diego C, Ferrer-Blasco T, BeldaSalmerón L. Iris-fixated toric phakic intraocular lens for myopic astigmatism. J Cataract Refract Surg 2012; 38:1166-1175

34. Dick HB, Budo C, Malecaze F, Güell JL, Marinho AAP, Nuijts RMMA, Luyten GPM, Menezo JL, Kohnen T. Foldable Artiflex phakic intraocular ens for the correction of myopia; two-year follow-up results of a prospective European multicenter study. Ophthalmology 2009; 116:671-677

35. Qasem Q, Kirwan C, O'Keefe M. 5-year prospective follow-up of Artisan phakic intraocular lenses for the correction of myopia, hyperopia and astig matism. Ophthalmologica 2010; 224:283-290

36. Guber I, Mouvet V, Bergin C, Perritaz S, Othenin-Girard P, Majo F. Clinica outcomes and cataract formation rates in eyes 10 years after posterior phakic lens implantation for myopia. JAMA Ophthalmol 2016; 134:487-494

37. McBrien NA, Adams DW. A longitudinal investigation of adult-onset and adult-progression of myopia in an occupational group; refractive and biometric findings. Invest Ophthalmol Vis Sci 1997; 38:321-333

38. Gudmundsdottir E, Arnarsson A, Jonasson F. Five-year refractive changes in an adult population; Reykjavik Eye Study. Ophthalmology 2005 112:672-677

39. Armitage WJ, Dick AD, Bourne WM. Predicting endothelial cell loss and long-term corneal graft survival. Invest Ophthalmol Vis Sci 2003; 44:3326-3331

40. Bourne WM, Nelson LR, Hodge DO. Central corneal endothelial cell changes over a ten-year period. Invest Ophthalmol Vis Sci 1997; 38:779-782

41. Güell JL, Morral M, Gris O, Gaytan J, Sisquella M, Manero F. Evaluation of Verisyse and Artiflex phakic intraocular lenses during accommodation using Visante optical coherence tomography. J Cataract Refract Surg 2007; 33:1398-1404

42. Repetto R, Pralits JO, Siggers JH, Soleri P. Phakic iris-fixated intraocular lens placement in the anterior chamber: effects on aqueous flow. Invest Ophthalmol Vis Sci 2015; 56:3061-3068

43. Pérez-Santonja JJ, Iradier MT, Benítez del Castillo JM, Serrano JM, Zato MA. Chronic subclinical inflammation in phakic eyes with intraocular lenses to correct myopia. J Cataract Refract Surg 1996; 22:183-187

\section{OTHER CITED MATERIAL}

A. Consensus Refractiechirurgie; Februari 2006 Herzien: Juli 2009 en Jun 2013. Auteurs versie februari 2006 Aalders-Deenstra V, Beerthuizen J, Bolmers PJD, den Boon JM, Braakman R, Crobach PSJR, Eggink CA, Geerards AJM, Kraaijenga AD, Luger M, Luyten GPM, Odenthal M, Rijneveld A, van Rooij, Rouwen APJ, van Tilburg CJG, Tutein Nolthenius P, Trap NH, Verdoorn C. Aanvullingen herziene versie juli 2009 door: Bartels M, Beerthuizen J, Copper M, Landesz M, Lapid R, Van Nouhuijs H, Nuyts R, Wolter O, Van Rooy J, Trap N. Available at: http://www.ooglaseradvies.org/wp-content/ uploads/2011/03/consensus-refractiechirurgie-2009.pdf. Accessed April 28, 2019

Disclosures: Dr. Nuijts receives grants from Abbot Medical Optics, Inc., Bausch \& Lomb,Inc., Carl Zeiss Meditec AG, HumanOptics AG, Oculentis, and Ophtec BV; grants and personal fees from Alcon Laboratories, Inc.; and personal fees from ASICO LLC and Théa Pharma $\mathrm{GmbH}$, all outside the submitted work. None of the other authors has a financial or proprietary interest in any material or method mentioned.

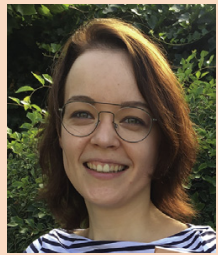

First author:

Soraya M.R. Jonker, MD

University Eye Clinic Maastricht, Maastricht University Medical Center, the Netherlands 